\title{
ANALISIS PENGARUH FAKTOR - FAKTOR MAKROEKONOMI TERHADAP NILAI AKTIVA BERSIH (NAB) REKSADANA SYARIAH PERIODE JANUARI 2015 - JUNI 2017
}

\author{
Muhammad Nizar Rusdiansyah \\ Mahasiswa Progam Studi S1 Ekonomi Islam - Fakultas Ekonomi dan Bisnis \\ Universitas Airlangga \\ Email: mochnizar.rusdiansyah-13@feb.unair.ac.id \\ Dina Fitrisia Septiarini \\ Departemen Ekonomi Syariah-Fakultas Ekonomi Dan Bisnis Universitas Airlangga \\ Email: dina.fitrisia@feb.unair.ac.id
}

\begin{abstract}
This study aims to determine the effect of SBI interest rate, gold price, and $\mathrm{JCl}$ on $\mathrm{Net}$ Asset Value (NAV) of shariah mutual funds partially or simultaneously. This research uses saturated sampling technique that is monthly data from variable interest rate of Bank Indonesia Certificate (X1), gold price (X2), Composite Stock Price Index (X3), and Net Asset Valve of Sharia Mutual Fund (Y) in January 2015 - June 2017. The results of this study show partially SBI and IHSG interest rate variables have a significant positive effect on NAV of Islamic mutual funds, while the variable significantly negative effect on NAV of Islamic mutual funds. Simultaneously variable of SBI interest rate, gold price, and IHSG have significant effect to net asset value of Islamic mutual fund in Indonesia.
\end{abstract}

\section{Keywords : SBI, Gold Price, IHSG, NAV of Sharia Mutual Funds}

\section{Pendahuluan}

Investasi pada saat ini sangat mudah dan beragam, kita dapat menginvestasikan dana kita melalui instrumen saham, deposito, obligasi bahkan dapat membeli instrumen yang dikeluarkan oleh negara seperti Sertifikat Bank Indonesia dan sebagainya. Instrumen investasi dalam hal ini yang paling sering diminati untuk saat ini adalah investasi pada instrumen saham karena dapat memberikan hasil yang lebih besar daripada instrumen lainnya.

Berdasarkan data pada Gambar 1.1 tentang evaluasi kinerja berbagai instrumen investasi tahun 2016 menunjukkan bahwa nilai return investasi saham adalah paling tinggi, sehigga membuat investasi saham menarik.

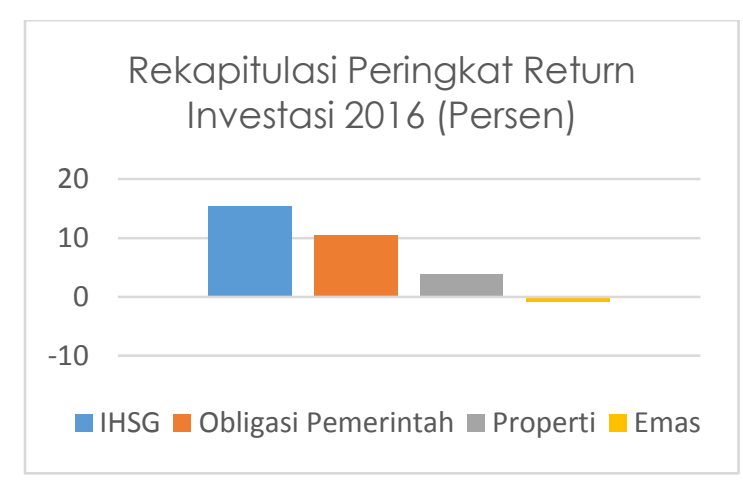

Sumber : Bank Indonesia. Data diolah.

\section{Gambar 1.1}

\section{Rekapitulasi Peringkat Return Investasi 2016}

Namun berinvestasi pada instrumen saham dengan return yang relatif lebih besar daripada instrumen yang lain bukanlah hal yang mudah untuk dilakukan. Para nasabah akan dihadapkan pada beberapa kendala dan risiko jika nasabah belum mempunyai pengetahun dan pengalaman dalam berivestasi di instrumen

${ }^{[1]} J u r n a l$ ini merupakan bagian dari Skripsi Muhammad Nizar Rusdiansyah NIM 041311433015 yang diuji pada tanggal 15 Januari 2017 
Rusdiansyah, et al/Jurnal Ekonomi Syariah Teori dan Terapan Vol. 5 No. 10 Oktober 2018: 856-872;

ANALISIS PENGARUH FAKTOR - FAKTOR MAKROEKONOMI TERHADAP NILAI AKTIVA BERSIH (NAB) REKSADANA SYARIAH PERIODE JANUARI 2015 - JUNI 2017

saham. Risiko tersebut antara lain adalah

investor mendapatkan capital lost, tidak mendapatkan deviden, risiko terkena suspend, risiko delisting saham, dan risiko likuidasi (May, 2013: 23).

Beberapa kendala tersebut membuat lembaga keuangan berpikir ulang untuk membuat produk yang memberikan hasil yang tinggi tetapi masih bisa dijangkau oleh semua kalangan nasabah. Sehingga munculah produk investasi yaitu reksadana.

Hal tersebut terus berlanjut hingga terdapat reksadana syariah. Lembaga keuangan menilai perkembangan produk syariah di Indonesia akan sangat diminati oleh penduduk Indonesia karena sebagian besar masyarakat Indonesia adalah seorang muslim, apalagi sebagai Negara yang mayoritas memeluk agama Islam telah diajarkan untuk menghindari instrumen investasi atau jual beli yang berbau riba, maysir, dan gharar. Sebagaimana yang telah disebutkan dalam Al-Qur'an surat Al-Baqarah ayat 275 sebagai berikut :

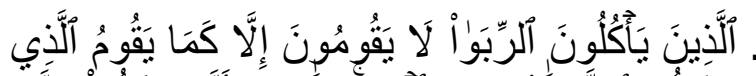

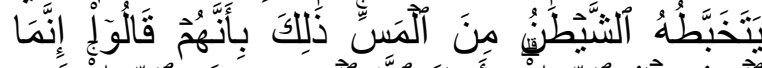

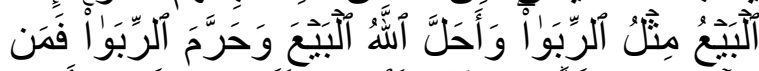

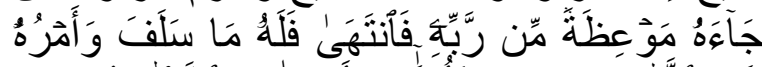

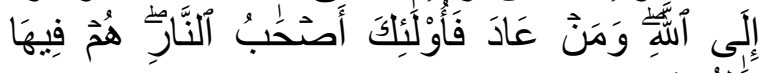

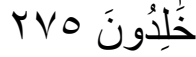

Allaz|i@na ya'kulu>nar-riba> la> yaqu>mu>na illa> kama> yaqu>mullaz|I yatakhabbat\}uhusy-syait\}a>nu minal-mass, $z \mid a>$ lika bi'annahum $q>$ alu> innamal-bai' $u$ mis|lur-riba>, wa ahallalla>hul-bai'a wa harramar-riba>, fa man ja>'ahu> mau'iz\}atum mir rabbihi@ fantaha> fa lahu> ma> salaf, wa amruhu> illalla>h, wa man 'a>da da ula>'ika as\}-h\}a>bun-na>r, humfi@ha>kha>lidu>n

Artinya: Orang-orang yang makan (mengambil) riba tidak dapat berdiri melainkan seperti berdirinya orang yang kemasukan syaitan lantaran (tekanan) penyakit gila. Keadaan mereka yang demikian itu, adalah disebabkan mereka berkata (berpendapat), sesungguhnya jual beli itu sama dengan riba, padahal Allah telah menghalalkan jual beli dan mengharamkan riba. Orang-orang yang telah sampai kepadanya larangan dari Tuhannya, lalu terus berhenti (dari mengambil riba), maka baginya apa yang telah diambilnya dahulu (sebelum datang larangan); dan urusannya (terserah) kepada Allah. Orang yang kembali (mengambil riba), maka orang itu adalah penghuni-penghuni neraka; mereka kekal di dalamnya. (Al-Qur'an Kementrian Agama $\mathrm{RI}, 2014$ : 65)

Kehadiran reksadana syariah diharapkan dapat membantu rencana pemerintah dalam merangsang kenaikan pertumbuhan ekonomi.

Ditengah perlambatan ekonomi tahun 2015 yaitu mengacu kepada catatan Badan Pusat Statistik (BPS), pertumbuhan ekonomi Indonesia tahun 2015 sebesar 4,79 persen merupakan yang terendah enam tahun terakhir (Kompas,07/02/2015).

Perlambatan ekonomi yang terjadi pada 2015 menjadikan hampir semua pasar keuangan ikut melambat. Hal tersebut salah satunya dipicu karena melemahnya pertumbuhan investasi. 
Rusdiansyah, et al/Jurnal Ekonomi Syariah Teori dan Terapan Vol. 5 No. 10 Oktober 2018: 856-872;

ANALISIS PENGARUH FAKTOR - FAKTOR MAKROEKONOMI TERHADAP NILAI AKTIVA BERSIH (NAB) REKSADANA SYARIAH PERIODE JANUARI 2015 - JUNI 2017

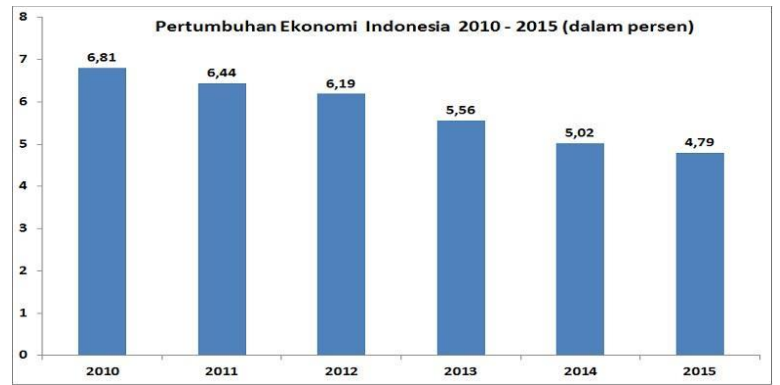

Sumber : BPS (Kompas, 07/02/2015).

Gambar 1.2

Angka Perumbuhan Ekonomi Indonesia

Permasalahan ekonomi global yang telah dilewati pada tahun 2015 seperti tingginya angka inflasi dan buruknya kinerja pasar investasi keuangan Negara juga berdampak pada pertumbuhan instrumen investasi syariah khususnya reksadana syariah.

Pertumbuhan dana kelolaan reksadana syariah pada tahun itu mengalami pelemahan meskipun dari sisi perkembangan jumlah unit reksadana mengalami kenaikan. Sampai pada tahun

$\begin{array}{ccccc}\text { Tahun } & \begin{array}{c}\text { Jumlah } \\ \text { Reksa } \\ \text { Dana }\end{array} & \begin{array}{c}\text { Pertumbuhan } \\ (\%)\end{array} & \begin{array}{c}\text { NAB } \\ \text { (Rp. } \\ \text { Miliar) }\end{array} & \begin{array}{c}\text { Pertumbuhan } \\ (\%)\end{array} \\ 2010 & 48 & & 5.225,78 & \\ 2011 & 50 & 4.16 & 5.564,79 & 6.48 \\ 2012 & 58 & 16 & 8.050,07 & 44.66 \\ 2013 & 65 & 12.06 & 9.432,19 & 17.16 \\ 2014 & 74 & 13.84 & 11.158 & 18.29 \\ 2015 & 93 & 25.67 & 11.019,43 & -1.24 \\ 2016 & 136 & 46.23 & 10.396,86 & -5.64\end{array}$

2016 menjadi titik balik bagi perlambatan

Sumber : Otoritas Jasa Keuangan (OJK). (Online). www.ojk.co.id. Data diolah tahun 2017.

\section{Gambar 1.2}

Pertumbuhan Reksadana Syariah di Indonesia ekonomi Indonesia yang telah terjadi pada tahun 2015. Berbagai produk pasar keuangan juga mulai membaik demikian juga dengan produk reksadana, khususnya reksadana syariah.

Beberapa hal dapat memengaruhi kinerja reksadana yang itu dapat berupa faktor dari luar dan ada beberapa faktor dari internal. Beberapa faktor yang memungkinkan dari luar yang dapat memengaruhi pertumbuhan Nilai Aktiva Bersih (NAB) reksadana yaitu harga Sertifikat Bank Indonesia (SBI), harga emas, dan harga Indeks Harga Saham Gabungan (IHSG). Penelitian yang dilakukan oleh Maulana (2013) membuktikan bahwa BI rate atau suku bunga SBI berpengaruh signifikan secara negatif terhadap kinerja reksa dana saham.

Menurut Wibowo (2011) dalam penelitiannya menyebutkan bahwa harga emas berpengaruh signifikan secara negatif terhadap perubahaan kinerja reksadana. Pada penelitiannya ketika kondisi pasar reksadana pendapatan tetap kurang stabil maka investor akan menginvestasikan ke instrumen emas sehingga membuat reksadana pendapatan tetap turun.

Menurut Sholihat, dkk. (2009) membuktikan bahwa kenaikan IHSG akan berpengaruh signifikan positif terhadap return reksadana saham. Dalam penelitiannya IHSG merupakan gabungan dari nilai saham yang tercatat dan 
Rusdiansyah, et al/Jurnal Ekonomi Syariah Teori dan Terapan Vol. 5 No. 10 Oktober 2018: 856-872;

ANALISIS PENGARUH FAKTOR - FAKTOR MAKROEKONOMI TERHADAP NILAI AKTIVA BERSIH (NAB) REKSADANA SYARIAH PERIODE JANUARI 2015 - JUNI 2017

diperdagangkan di bursa efek. Kenaikan

IHSG menunjukkan bahwa sebagian besar

atau semua saham mengalami kenaikan.

Sebaliknya, penurunan IHSG menunjukkan

sebagian besar atau semua saham sedang mengalami penurunan.

Berdasarkan latar belakang dan

peneltersebut peneliti melakukan penelitian yang diberi judul "Pengaruh Suku Bunga

Sertifikat Bank Indonesia (SBI), Harga Emas, dan Indeks Harga Saham Gabungan (IHSG) terhadap Nilai Aktiva Bersih (NAB) Reksadana Syariah periode Januari 2015 Juni 2017".

1) Rumusan Masalah

Berdasarkan latar belakang diatas, maka rumusan masalah dari penelitian ini adalah sebagai berikut :

1. Apakah suku bunga Sertifikat Bank Indonesia (SBI) berpengaruh parsial signifikan terhadap Nilai Aktiva Bersih (NAB) reksadana syariah periode Januari 2015 - Juni $2017 ?$

2. Apakah pengaruh harga emas berpengaruh parsial signifikan terhadap Nilai Aktiva Bersih (NAB) reksadana syariah periode Januari 2015 - Juni $2017 ?$

3. Apakah pengaruh Indeks Harga Saham Gabungan (IHSG) berpengaruh parsial signifikan terhadap Nilai Aktiva Bersih (NAB) reksadana syariah periode Januari 2015 - Juni 2017 ?
4. Apakah suku bunga Sertifikat Bank Indonesia (SBI), harga emas, dan Indeks Harga Saham Gabungan (IHSG) secara simultan signifikan berpengaruh terhadap Nilai Aktiva Bersih (NAB) reksadana syariah periode Januari 2015 - Juni $2017 ?$

2) Tujuan Penelitian Berdasarkan perumusan masalah di atas, maka tujuan dari penelitian ini adalah sebagai berikut :

1. Untuk mengetahui pengaruh parsial signifikan suku bunga Sertifikat Bank Indonesia (SBI) terhadap Nilai Aktiva Bersih (NAB) reksadana syariah periode Januari 2015 - Juni 2017.

2. Untuk mengetahui pengaruh parsial signifikan harga emas terhadap Nilai Aktiva Bersih (NAB) reksadana syariah periode Januari 2015 - Juni 2017.

3. Untuk mengetahi pengaruh parsial signifikan Indeks Harga Saham Gabungan (IHSG) terhadap Nilai Aktiva Bersih (NAB) reksadana syariah periode Januari 2015 - Juni 2017.

4. Untuk mengetahui pengaruh suku bunga Sertifikat Bank Indonesia (SBI), harga emas, dan Indeks Harga Saham Gabungan (IHSG) secara simultan signifikan terhadap Nilai Aktiva Bersih (NAB) reksadana syariah periode Januari 2015 - Juni 2017. 
Rusdiansyah, et al/Jurnal Ekonomi Syariah Teori dan Terapan Vol. 5 No. 10 Oktober 2018: 856-872;

ANALISIS PENGARUH FAKTOR - FAKTOR MAKROEKONOMI TERHADAP NILAI AKTIVA BERSIH (NAB) REKSADANA SYARIAH PERIODE JANUARI 2015 - JUNI 2017

\section{Landasan Teori}

1. Investasi

Investasi adalah penanaman modal untuk satu atau lebih aktiva yang dimiliki dan biasanya berjangka waktu lama dengan harapan mendapatkan keuntungan di masa - masa akan datang (Sunariyah, 2004: 4).

Pada aktitivitas investasi finansial, pemilik dana dalam membelanjakan dananya untuk investasi pada suatu entitas tertentu dapat melalui 2 cara yaitu : investasi langsung (direct investing) dan investasi tidak langsung (indirect investing). Investasi langsung diartikan sebagai suatu pemilikan surat-surat berharga secara langsung dalam suatu entitas yang secara resmi telah go public dengan harapan akan mendapat keuntungan berupa penghasilan deviden dan capital gain. Sedangkan investasi tidak langsung yaitu ketika investor tidak mebeli langsung surat kepemilikan atau obligasi suatu entitas melainkan melalui pihak perantara (intermediary) yang berperan sebagai pialang (broker) yang membantu investor dalam mengarahkan aktivitas investasinya agar lebih efektif dalam melakukan aktivitas investasi (Jogiyanto, 2010: 7).

Tujuan aktivitas investasi keuangan adalah keuntungan atau return. Menurut Corrado dan Jordan (2000; 5) return from investment security is cash flow and capital gaint/loss.
2. Investasi Syariah

Investasi syariah adalah kegiatan investasi yang berlandaskan prinsip-prinsip syariah, baik itu investasi pada sektor keuangan ataupun rill. Dalam hal ini Islam mengajarkan investasi yang menguntungkan bagi semua pihak dan melarang manusia untuk mencari dan mendapatkan rezeki melalui spekulasi atau berbagai cara lainnya yang sifatnya merugikan orang lain (Ryandono, 2009: 23).

Dalam agama Islam, Invesasi sangat dianjurkan bagi setiap muslim. Konsep investasi selain sebagai pengetahuan juga bernuansa spiritual karena menggunakan norma syariah, sekaligus merupakan hakikat dari sebuah ilmu dan amal (Huda dan Nasution. 2007:18) Hal ini dijelaskan pada Al - Qur'an surat An - Nisa ayat 9, yaitu sebagai berikut :

Artinya : Dan hendaklah takut kepada Allah orang-orang yang seandainya meninggalkan dibelakang mereka anakanak yang lemah, yang mereka khawatir terhadap (kesejahteraan) mereka. Oleh sebab itu hendaklah mereka bertakwa kepada Allah dan hendaklah mereka mengucapkan perkataan yang benar. (AlQur'an Kementrian Agama RI, 2014: 112)

Ayat ini menjelaskan bahwa kita tidak boleh dzurriat dhi'afa atau meninggalkan keturunan yang lemah baik itu dalam bentuk moral maupun material dan berpesan agar umat Islam menyiapkan generasi penerus yang berkualitas sehingga anak mampu mengaktualisasikan potensinya sebagai bekal kehidupan dimasa akan datang (Shihab, 2002: 355). Al 
Rusdiansyah, et al/Jurnal Ekonomi Syariah Teori dan Terapan Vol. 5 No. 10 Oktober 2018: 856-872;

ANALISIS PENGARUH FAKTOR - FAKTOR MAKROEKONOMI TERHADAP NILAI AKTIVA BERSIH (NAB) REKSADANA SYARIAH PERIODE JANUARI 2015 - JUNI 2017

- Qur'an menyeru kita untuk senantiasa mempersiapkan kebutuhan keturunan sehingga kesejahteraan mereka dapat terpenuhi yaitu salah satunya dengan melakukan investasi.

\section{Reksadana}

Reksadana adalah portofolio aset keuangan yang terdiversifikasi, dicatatkan sebagai perusahaan investasi yang terbuka, yang menjual saham kepada masyarakat dengan harga penawaran dan penarikannya pada nilai aktiva bersihnya (Manurung, 2007: 1).

Investasi pada reksadana dapat digunakan oleh semua kalangan masyarakat. Investasi ini juga baik digunakan untuk investor yang belum cukup pengalaman dan belum mengerti akan investasi karena terdapat manajer investasi yang membantu investor dalam mengelola dana investasinya. Sehingga memudahkan bagi investor baru untuk membelanjakan dananya untuk investasi. Manajer investasi biasanya melakukan perputaran dana tersebut dengan cara membeli surat - surat berharga, seperti saham, obligasi, SBI (Sertifikat Bank Indonesia), dan berbagai efek lainnya atau bisa ditabungkan dalam bentuk deposito.

Reksadana memiliki beberapa manfaat yang apabila menyimpan dana reksadana adalah sebagai berikut (Sudarsono, 2004: 208-209):

a. Pemodal walaupun tidak memiliki dana yang cukup besar dapat melakukan diversifikasi investasi dalam efek, sehingga dapat memperkecil risiko.

b. Reksadana mempermudah pemodal untuk melakukan investasi di pasar modal. Menentukan saham yang baik untuk dibeli bukanlah pekerjaan yang mudah, namun memerlukan pengetahuan dan keahlian tersendiri.

c. Efesiensi waktu dengan melakukan investasi pada reksadana, dana tersebut dikelola oleh manajer investasi professional maka pemodal tidak perlu memantau kinerja investasinya hal tesebut telah dialihkan kepada manajer investasi tersebut.

\section{Reksadana Syariah}

Reksadana syariah merupakan salah satu bentuk pengelolaan reksadana yang bertujuan untuk memberikan keuntungan bagi investor dari sumber dan cara yang bersih dan sesuai dengan syariat Islam (Sjahputra, 2005: 21). Pengelolaan dan mekanisme transaksi reksadana syariah harus sesuai dengan Al - Qur'an dan Hadits. Sama seperti investasi syariah pada umumnya reksadana syariah terdapat screening dan filtering yaitu menseleksi entitas yang bersangkutan agar tidak melanggar kaidah syariah. Hal tersebut untuk menghindarkan transaksi reksadana syariah dan juga melindungi investor dari transaksi yang haram. 
Rusdiansyah, et al/Jurnal Ekonomi Syariah Teori dan Terapan Vol. 5 No. 10 Oktober 2018: 856-872;

ANALISIS PENGARUH FAKTOR - FAKTOR MAKROEKONOMI TERHADAP NILAI AKTIVA BERSIH (NAB) REKSADANA SYARIAH PERIODE JANUARI 2015 - JUNI 2017

Pada Reksadana syariah juga terdapat proses cleansing yaitu membersihkan pendapatan yang dianggap diperoleh dari transaksi haram menurut syariah. Dana tersebut digunakan untuk hadiah, memberi santunan ke anak yatim dan panti asuhan, kegiatan bantuan musibah bencana, dan kegiatan amal yang lain.

Sedangkan menurut Burhanuddin (2008: 74) Reksadana Syariah adalah reksadana yang beroperasi menurut ketentuan dan prinsip-prinsip syariah Islam, baik dalam bentuk akad antara pemodal sebagai pemilik harta (shahib al-mal/ rabb al-mal) dengan manajer investasi sebagai wakil shahib al-mal, maupun antara manajer investasi sebagai wakil shahib almal dengan pengguna investasi.

5. Nilai Aktiva Bersih (NAB) Reksadana Syariah

Nilai Aktiva Bersih adalah merupakan aktiva setelah dikurangi kewajiban-kewajiban reksadana tersebut (Rahardjo, 2004: 71). NAB reksadana adalah salah satu penentu dalam penentuan harga reksadana selain dari jumlah unit penyertaan. Harga reksadana menurut Sudarsono (2004: 207) adalah jumlah NAB dibagi dengan jumlah unit penyertaan (saham diterbitkan) pada periode tertentu.

Menurut Elvira dan Fiteriyanto (1997: 23) Nilai Aktiva bersih merupakan data historis untuk melihat dan mengamati data- data tinggi rendahnya pengambilan investasi dari reksadana, sehingga untuk melihat tingkat perkembangan pasar reksadana dapat menjadikan Nilai Aktiva Bersih reksadana sebagai indikator dalam melihat portofolio dana reksadana yang terkumpul.

\section{Suku Bunga Sertifikat Bank Indonesia (SBI)}

Sertifikat bank Indonesia (SBI) pada prinsipnya adalah surat berharga atas tunjuk atas rupiah yang diterbitkan dengan sistem diskonto oleh bank Sentral Indonesia sebagai pengakuan utang berjangka waktu pendek (Darmawi, 2005:93).

Menurut (Kasmir, 2005:224) Sertifikat bank Indonesia (SBI) merupakan surat berharga yang diterbitkan oleh bank sentral (Bank Indonesia). Penerbitan SBI dilakukan atas tunjuk dengan nominal tertentu dan penerbitan SBI biasanya dilakukan dengan kebijakan pemerintah operasi pasar terbuka dalam masalah penanggulangan jumlah vang yang beredar. Suku bunga Sertifikat Bank Indonesia dikeluarkan oleh Bank Indonesia sebagai instrumen operasi moneternya untuk mengarahkan suku bunga pasar agar berada di sekitar Bl rate.

Kepemilikan dari Sertifikat Bank Indonesia (SBI) dapat dimiliki oleh masyarakat maupun bank umum. Bank dapat membeli SBI di pasar perdana sedangkan masyarakat hanya diperbolehkan membeli di pasar sekunder. 
Rusdiansyah, et al/Jurnal Ekonomi Syariah Teori dan Terapan Vol. 5 No. 10 Oktober 2018: 856-872;

ANALISIS PENGARUH FAKTOR - FAKTOR MAKROEKONOMI TERHADAP NILAI AKTIVA BERSIH (NAB) REKSADANA SYARIAH PERIODE JANUARI 2015 - JUNI 2017

Sistem yang digunakan oleh Bank Indonesia dalam menerbitkan Sertifikat Bank Indonesia adalah dengan sistem lelang dengan sistem pengembalian diskonto atau bunga. Bank Indonesia dalam melakukan lelang Sertifikat Bank Indonesia (SBI) untuk menyerap likuiditas yang beredar di pasar dengan meminjam dana dari pasar dan membayar kembali bersama diskontonya setelah jatuh tempo.

Metode lelang penerbitan SBI menurut peraturan Bank Indonesia Nomor 4/9/PBI/2002 tanggal 18 November 2002 menggunakan 2 (dua) cara yaitu melalui Variable Rate Tender (peserta lelang mengajukan penawaran kuantitas dengan tingkat diskonto yang ditetapkan oleh Bank Indonesia) dan dengan Fixed Rate Tender (peserta lelang mengajukan penawaran kuantitas dengan tingkat diskonto yang ditetapkan oleh Bank Indonesia).

Pada praktiknya Suku Bunga Sertifikat bank Indonesia (SBI) merupakan langkah dalam melakukan intervensi terhadap perekonomian suatu negera. Dengan adanya penetapan suku bunga SBI secara tepat diharapkan mampu menjaga perekonomian suatu negara tersebut agar tetap stabil khususnya dalam hal ini menjaga laju inflasi tetap stabil sehingga harga yang beredar dipasar dapat terkontrol dengan baik.

7. Harga Emas

Emas adalah jenis logam yang memiliki nilai berharga yang banyak digunakan sebagai cadangan devisa, standar kevangan suatu negara, bahan dasar perhiasan maupun bahan elektronik. Harga emas adalah sejumlah vang yang dikorbankan atau dibayarkan untuk memperoleh komoditi atau produk berupa emas (Desriani dan Rahayu, 2013: 149).

Emas merupakan salah satu bentuk investasi yang cenderung bebas risiko. Emas dianggap lebih baik untuk lindung nilai terhadap inflasi (Sunaryah,2007). Stabilnya harga emas dapat menarik minat investor untuk berinvestasi emas terutama pada saat kondisi pasar keuangan sedang buruk.

Emas Dunia untuk dijadikan patokan untuk setiap harga emas di seluruh dunia. Harga emas adalah harga spot yang terbentuk dari akumulasi penawaran dan permintaan di pasar emas London (Raraga et al., 2012:82). Sejak tahun 1968, standar pasar emas London dijadikan patokan harga emas dunia. Sistem yang digunakan dikenal dengan London Gold Fixing (Witjaksono, 2010: 52)

8. Indeks Harga Saham Gabungan

Indeks harga saham gabungan seluruh saham adalah suatu nilai yang digunakan untuk mengukur kinerja gabungan seluruh saham yang tercatat di suatu efek. Maksud gabungan seluruh saham ini adalah kinerja saham yang dimasukkan dalam perhitungan seluruh saham yang tercatat dibursa tersebut (Sunaryah, 1997: 126). 
Rusdiansyah, et al/Jurnal Ekonomi Syariah Teori dan Terapan Vol. 5 No. 10 Oktober 2018: 856-872;

ANALISIS PENGARUH FAKTOR - FAKTOR MAKROEKONOMI TERHADAP NILAI AKTIVA BERSIH (NAB) REKSADANA SYARIAH PERIODE JANUARI 2015 - JUNI 2017

Menurut Pramulia (2009: 30) Indeks

Harga Saham Gabungan (IHSG)

merupakan suatu indikator yang secara umum mencerminkan kecenderungan pergerakan harga saham di Bursa Efek Indonesia.

Indeks Harga Saham Gabungan atau Composite Stock Price Index (IHSG) digunakan untuk mengukur kinerja kerja saham yang tercatat di suatu bursa efek yang dipantau oleh Bursa Efek Indonesia (BEI) dan untuk merepresentasikan pergerakan harga saham perusahaanperusahaan yang tercatat dalam IHSG. Saham yang terdaftar pada IHSG terdiri dari perusahaan dibeberapa macam sektor seperti pertanian, perkebunan, pertambangan, keuangan, industri, konsumsi, properti, dan lainnya yang mempunyai track record bagus dan masuk standar yang diberikan oleh Bursa Efek Indonesia.

Menurut Jogiyanto (2009: 102) rumus yang digunakan dalam menghitung IHSG adalah sebagai berikut :

$\mathrm{HSG}_{\dagger}=\frac{\text { Nilai Pasar }{ }_{+}}{\text {Nilai Dasar }} \times 100$

Keterangan :

IHSG I $_{\text {Indeks Harga Saham }}$ Gabungan hari ke- $\dagger$

Nilai Pasar ${ }_{+}=$Rata-rata tertimbangn nilai pasar (Jumlah lembar tercatat di bursa dikalikan dengan harga pasar per lembarnya) dari saham umum dan saham preferen pada hari ke- $\dagger$

Nilai dasar = Nilai dasar pasar saham dimulai dari tanggal 10 Agustus 1982.

Berdasarkan latar belakang, rumusan masalah, tujuan penelitian, kajian pustaka dan penelitian sebelumnya, maka dalam penelitian ini akan dirumuskan hipotesis yaitu:

$\mathrm{H}_{1}$ : Suku bunga Sertifikat Bank Indonesia (SBI) berpengaruh signifikan terhadap Nilai Aktiva Bersih reksadana syariah

$\mathrm{H}_{2}$ : Harga emas berpengaruh signifikan terhadap Nilai Aktiva Bersih reksadana syariah

$\mathrm{H}_{3}$ : Indeks Harga Saham Gabungan (IHSG) berpengaruh signifikan terhadap Nilai Aktiva Bersih reksadana syariah

$\mathrm{H}_{4}$ : Suku bunga Sertifikat Bank Indonesia (SBI), Harga Emas, dan Indeks Harga Saham Gabungan (IHSG) berpengaruh signifikan terhadap Nilai Aktiva Bersih reksadana syariah.

\section{Metode Penelitian}

Pendekatan penelitian yang digunakan pada penelitian ini adalah pendekatan penelitian kuantitatif. Teknik analisis yang digunakan untuk mengetahui hubungan antar variabel menggunakan teknik analisis regresi linier berganda. Hubungan antar variabel yang dimaksud dalam penelitian ini adalah untuk mengetahui pengaruh baik secara parsial 
Rusdiansyah, et al/Jurnal Ekonomi Syariah Teori dan Terapan Vol. 5 No. 10 Oktober 2018: 856-872;

ANALISIS PENGARUH FAKTOR - FAKTOR MAKROEKONOMI TERHADAP NILAI AKTIVA BERSIH (NAB) REKSADANA SYARIAH PERIODE JANUARI 2015 - JUNI 2017

maupun secara simultan antara variabel suku bunga Sertifikat Bank Indonesia (SBI), harga emas, Indeks Harga Saham Gabungan (IHSG) terhadap Nilai Aktiva Bersih (NAB) reksadana syariah di Indonesia.

Metode penelitian yang digunakan dalam penelitian ini yaitu menggunakan teknik sampling jenuh. Sampling jenuh adalah teknik penentuan sampel bila semua anggota populasi digunakan sebagai sampel. Sampel pada penelitian ini adalah suku bunga SBI, harga emas, IHSG, dan Nilai Aktiva Bersih reksadana syariah periode Januari 2015 - Juni 2017.

Jenis data yang digunakan dalam penelitian ini adalah menggunakan jenis data sekunder yang berbentuk time series.

1. Data suku bunga SBI merupakan data bulanan yang berasal dari kebijakan moneter pemerintah melalui Bank Indonesia diperoleh dari situs resmi Bank Indonesia periode Januari 2015 - Juni 2017.

2. Data harga emas merupakan data bulanan dengan satuan rupiah per gram diperoleh dari data harga emas harian Indonesia yang diperoleh di situs http://hargaemas.org pada periode Januari 2015 - Juni 2017.

3. Data IHSG merupakan data bulanan yang dikeluarkan oleh Bursa Efek Indonesia (BEI) dan diperoleh dari

situs resmi Otoritas Jasa Keungan (OJK) periode Januari 2015 - Juni 2017.

4. Data bulanan Nilai Aktiva Bersih reksadana diperoleh melalui situs resmi Otoritas Jasa Keuangan (OJK) pada periode Januari 2015 - Juni 2017

Prosedur yang digunakan untuk pengumpulan data pada penelitian ini menggunakan studi kepustakaan (Library Research) yaitu peneliti mengumpulkan data yang berasal dari literatur yang relevan dengan objek yang dikaji peneliti yaitu seperti buku pustaka, jurnal, skripsi,makalah kuliah umum, serta internet. Teknik analisis dan pengolahan data yang dilakukakan peneliti pada penelitian ini adalah menggunakan teknik analisis regresi linier berganda dan pengolahan datanya menggunakan SPSS.

\section{Analisis Regresi dan Pengujian Hipotesis}

1. Analisis Regresi Linier Berganda

Berdasarkan hasil pengujian analisis linier berganda pada tabel diatas, maka dapat disimpulkan sebagai berikut:

$Y=-83,485+38,111 X_{1}-0,001 X_{2}+0,049 X_{3}$

Variabel dependen dalam model analisis ini adalah Nilai Aktiva Bersih reksadana syariah $(Y)$, sedangkan variabel independennya adalah suku bunga SBI $\left(X_{1}\right)$, harga emas $\left(X_{2}\right)$, dan IHSG $\left(X_{3}\right)$. Hasil 
Rusdiansyah, et al/Jurnal Ekonomi Syariah Teori dan Terapan Vol. 5 No. 10 Oktober 2018: 856-872;

ANALISIS PENGARUH FAKTOR - FAKTOR MAKROEKONOMI TERHADAP NILAI AKTIVA BERSIH (NAB) REKSADANA SYARIAH PERIODE JANUARI 2015 - JUNI 2017

persamaan analisis regresi linier berganda

tersebut dapat dijelaskan sebagai berikut:

a) Nilai konstanta sebesar $-83,485$ menunjukkan apabila variabel SBI, harga emas, dan IHSG besarnya nol atau konstan, maka nilai NAB reksadana syariah adalah sebesar adalah sebesar $-83,485$.

b) Koefisien regresi $\mathrm{SBI}$ sebesar 38,111 memiliki koefisien yang searah dengan NAB reksadana syariah. Setiap kenaikan sebesar satu satuan dari SBI, menyebabkan kenaikan $N A B$ reksadana syariah sebesar 38,111. Begitu pula sebaliknya, setiap penurunan sebesar satu satuan dari SBI, menyebabkan penurunan NAB reksadana syariah sebesar satu satuan dengan asumsi bahwa variabel yang lain adalah konstan.

c) Koefisien regresi harga emas sebesar $-0,001$ memiliki koefisien yang tidak searah dengan $N A B$ reksadana syariah. Setiap kenaikan sebesar satu satuan dari SBI, menyebabkan penurunan NAB reksadana syariah sebesar -0,001. Begitu pula sebaliknya, setiap penurunan sebesar satu satuan dari harga emas, menyebabkan kenaikan NAB reksadana syariah sebesar satu satuan dengan asumsi bahwa variabel yang lain adalah konstan. d) Koefisien regresi IHSG sebesar 0,049 memiliki koefisien yang searah dengan NAB reksadana syariah. Setiap kenaikan sebesar satu satuan dari IHSG, menyebabkan kenaikan NAB reksadana syariah sebesar 0,049 . Begitu pula sebaliknya, setiap penurunan sebesar satu satuan dari $S B I$, menyebabkan penurunan NAB reksadana syariah sebesar satu satuan dengan asumsi bahwa variabel yang lain adalah konstan.

2. Uji Hipotesis

a. Uji $\dagger$

Tabel 3.4

Tabel Uji $\dagger$

\begin{tabular}{|cl|c|c|}
\hline \multicolumn{2}{|c|}{ Model } & t & Sig \\
\hline 1 & (Constant) & $-0,869$ & 0,393 \\
& SBI & 5,104 & 0,000 \\
Harga Emas & $-6,225$ & 0,000 \\
IHSG & 6,941 & 0,000 \\
\cline { 2 - 3 } & & & \\
\hline
\end{tabular}

a. Dependent Variable: Nilai Aktiva Bersih Reksadana Sumber: Data diolah peneliti. Berdasarkan hasil dari Uji † diatas, maka dapat dijelaskan sebagai berikut :

a) Variabel SBI diperoleh $\dagger$ hitung sebesar 5,104, lebih besar daripada $\dagger$ tabel sebesar 2,478 († hitung 5,104 > 2,478) dengan nilai signifikansi sebesar 0,000, kurang dari tingkat signifikansi yang telah ditentukan 
Rusdiansyah, et al/Jurnal Ekonomi Syariah Teori dan Terapan Vol. 5 No. 10 Oktober 2018: 856-872;

ANALISIS PENGARUH FAKTOR - FAKTOR MAKROEKONOMI TERHADAP NILAI AKTIVA BERSIH (NAB) REKSADANA SYARIAH PERIODE JANUARI 2015 - JUNI 2017

yaitu sebesar 0,05 (sig. <a 0,000<

0,05), maka dapat disimpulkan bahwa variabel SBI secara parsial berpengaruh signifikan terhadap Nilai Aktiva Bersih (NAB) reksadana syariah.

b) Variabel harga emas diperoleh $\dagger$ hitung sebesar $-6,225$ dengan nilai signifikansi sebesar 0,000, kurang dari tingkat signifikansi yang telah ditentukan yaitu sebesar 0,05 (sig. <a $0,000<0,05)$, maka dapat disimpulkan bahwa variabel harga emas secara parsial berpengaruh signifikan terhadap Nilai Aktiva Bersih (NAB) reksadana syariah.

c) Variabel IHSG diperoleh $†$ hitung sebesar 6,941, lebih besar daripada $\dagger$ tabel sebesar 2,478 († hitung 6,941 > 2,478) dengan nilai signifikansi sebesar 0,000, kurang dari tingkat signifikansi yang telah ditentukan yaitu sebesar 0,05 (sig. <a 0,000< 0,05), maka dapat disimpulkan bahwa variabel IHSG secara parsial berpengaruh signifikan terhadap Nilai Aktiva Bersih (NAB) reksadana syariah.

b. Uji $F$

\begin{tabular}{|c|c|c|c|c|c|}
\hline Model & $\begin{array}{c}\text { Sum of } \\
\text { Squares }\end{array}$ & Df & $\begin{array}{c}\text { Mean } \\
\text { Square }\end{array}$ & F & Sig. \\
\hline $\begin{array}{c}1 \\
\text { Regression } \\
\quad \text { Residual }\end{array}$ & 9964.037 & 3 & 3321.346 & 31.123 & $.000^{\mathrm{b}}$ \\
$\quad 2774.600$ & 26 & 106.715 & & \\
Total & 12738.637 & 29 & & & \\
\hline
\end{tabular}

a. Dependent Variable: Nilai Aktiva Bersih Reksadana b. Predictors: (Constant), IHSG, EMAS, SBI

Sumber: Data diolah peneliti.

Berdasarkan hasil dari Uji F diatas, diperoleh F hitung sebesar 31,123 dengan nilai signifikansi sebesar 0,000. F tabel dengan df penyebut sebesar 26 dan df pembilang sebesar 3 yaitu menunjukkan angka, maka hal ini menyimpulkan bahwa $F$ hitung $>F$ tabel $(a 31,123>2,96)$. Tingkat signifikansi lebih kecil dari tingkat signifikansi yang telah ditentukan yaitu sebesar 0,05 (a $0,000<0,05)$. Maka dapat disimpulkan bahwa variabel SBI, harga emas, dan IHSG berpengaruh simulltan signifikan terhadap Nilai Aktiva Bersih (NAB) reksadana syariah.

\section{Koefisien Determinasi}

Nilai koefisien determinasi $\left(\mathrm{R}^{2}\right)$ dalam penelitian ini sebesar 0,782 atau sebesar $78,2 \%$, sehingga dapat disimpulkan bahwa variabel independen yaitu SBI, harga emas, dan IHSG dapat menjelaskan variabel Nilai Aktiva bersih Reksadana Syariah sebagai variabel dependen sebesar 78,2\%, sedangkan sisanya sebesar 11,8 \% dijelaskan oleh variabel-vaiabel yang lain diluar variabel yang diteliti.

\section{Kesimpulan dan Saran}


Rusdiansyah, et al/Jurnal Ekonomi Syariah Teori dan Terapan Vol. 5 No. 10 Oktober 2018: 856-872;

ANALISIS PENGARUH FAKTOR - FAKTOR MAKROEKONOMI TERHADAP NILAI AKTIVA BERSIH (NAB) REKSADANA SYARIAH PERIODE JANUARI 2015 - JUNI 2017

1. Kesimpulan

Berdasarkan hasil analisis dan pembahasan tentang pengaruh dari Suku bunga Sertifikat Bank Indonesia (SBI), harga emas, dan Indeks Harga Saham Gabungan (IHSG) terhadap Nilai Aktiva Bersih (NAB) reksadana syariah periode Januari 2015 Juni 2017, maka dapat disimpulkan sebagai berikut:

a) Suku bunga Sertifikat Bank Indonesia (SBI) berpengaruh signifikan parsial terhadap Nilai Aktiva Bersih (NAB) reksadana syariah pada periode Januari 2015 - Juni 2017.

Namun hasil penelitian ini tidak mendukung penelitian terdahulu Maulana (2013) karena pada penelitian ini nilai koefisien regresi suku bunga SBI yang dihasilkan dalam penelitian ini sebesar 38,111 artinya harga emas memiliki hubungan positif dengan NAB reksadana syariah disebabkan kenaikan suku bunga SBI juga berpengaruh positif terhadap instrumen lain yang berhungan dengan suku bunga SBI.

Karena didalam penelitian ini variabel yang diteliti menggunakan data NAB reksadana secara kumulatif yang didalamnya terdapat berbagai macam instrumen investasi, termasuk reksadana campuran, pasar vang, pendapatan tetap, dan terproteksi yang mempunyai hubungan dengan instrumen suku bunga SBI.

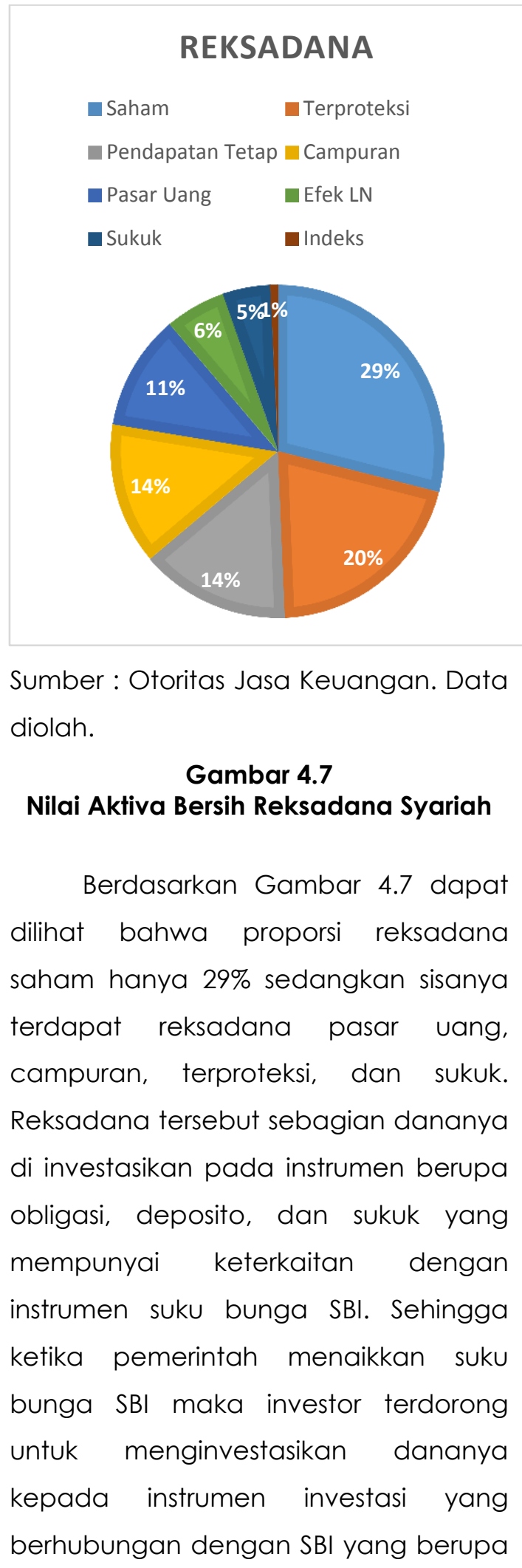


Rusdiansyah, et al/Jurnal Ekonomi Syariah Teori dan Terapan Vol. 5 No. 10 Oktober 2018: 856-872;

ANALISIS PENGARUH FAKTOR - FAKTOR MAKROEKONOMI TERHADAP NILAI AKTIVA BERSIH (NAB) REKSADANA SYARIAH PERIODE JANUARI 2015 - JUNI 2017

deposito dan juga reksadana-

reksadana tersebut.

b) Harga emas berpengaruh signifikan parsial terhadap Nilai Aktiva Bersih (NAB) reksadana syariah pada periode Januari 2015 - Juni 2017.

Hubungan dari varabel harga emas dengan variabel NAB reksadana syariah memiliki hubugan signifikan negatif, sesuai dengan penelitian sebelumnya Wibowo (2011) dalam penelitiannya menyebutkan bahwa harga emas berpengaruh signifikan secara negatif terhadap perubahaan kinerja reksadana. Pada penelitiannya ketika kondisi pasar reksadana pendapatan tetap kurang stabil maka investor akan menginvestasikan ke instrumen emas sehingga membuat reksadana pendapatan tetap turun.

Hal tersebut sesuai dengan penelitian Iman, 2009 dalam Rusbariandi (2009: 48), yang menyebutkan bahwa ketika potensi imbalan (return) berinvestasi dalam saham atau obligasi tidak lagi menarik dan dianggap tidak mampu mengkompensasi risiko yang ada maka investor akan mengalihkan dananya ke dalam aset riil seperti logam mulia atau properti yang dianggap lebih layak dan aman.

c) Indeks Harga Saham Gabungan (IHSG) berpengaruh signifikan parsial terhadap
Nilai Aktiva Bersih (NAB) reksadana syariah pada periode Januari 2015 Juni 2017. Hasil penelitian ini mendukung penelitian sebelumnya yaitu menurut Sholihat et al. (2009) Indeks Harga Saham Gabungan merupakan cerminan dari kondisi bursa efek, karena IHSG merupakan gabungan dari nilai saham yang tercatat dan diperdagangkan di bursa efek. Kenaikan IHSG menunjukkan bahwa sebagian besar atau semua saham mengalami kenaikan. Sebaliknya, penurunan IHSG menunjukkan sebagian besar atau semua saham sedang mengalami penurunan. Hal ini menunjukkan bahwa kenaikan IHSG akan berpengaruh signifikan positif terhadap return reksadana saham.

Ketika pasar IHSG sedang lesu maka pasar reksadana syariah juga ikut menurun. Karena investor antara IHSG dan reksadana syariah berada di dalam pasar yang sama. Sehingga ketika IHSG sedang memiliki tren negatif maka investor cenderung menempatkan dananya kedalam instrumen investasi yang lain.

d) Suku bunga Sertifikat Bank Indonesia $(S B I)$, harga emas, dan Indeks Harga Saham Gabungan (IHSG) berpengaruh signifikan simultan terhadap Nilai Aktiva Bersih (NAB) reksadana syariah pada periode Januari 2015 - Juni 2017. Hasil 
Rusdiansyah, et al/Jurnal Ekonomi Syariah Teori dan Terapan Vol. 5 No. 10 Oktober 2018: 856-872;

ANALISIS PENGARUH FAKTOR - FAKTOR MAKROEKONOMI TERHADAP NILAI AKTIVA BERSIH (NAB) REKSADANA SYARIAH PERIODE JANUARI 2015 - JUNI 2017

penelitian ini sesuai dengan Dornbusch

dan Fischer (1994:43) yang

mengatakan terdapat keseimbangan

dalam pasar aset seperti vang, obligasi,

saham, dan bentuk kekayaan lainnya sehingga dapat dilihat hubungan antara variabel makro ekonomi tersebut dengan NAB reksadana syariah. Sehingga dapat dibuktikan bahwa variabel makroekonomi memiliki hubungan yang erat dengan pasar aset sehingga bila terdapat fluktuasi keadaan moneter pasti akan menyebabkan fluktuasi terhadap NAB reksadana syariah.

2. Saran

Berdasarkan simpulan tersebut,
saran yang disampaikan dalam
penelitian ini adalah:

a. Bagi pemerintah dalam hal ini Otoritas Jasa Keungan yang mempunyai wewenang untuk mengatur serta mengawasi pasar modal dan Bank Indonesia sebagai penyelenggara sistem moneter di Indonesia untuk tetap menjaga kestabilan moneter dan juga mampu mengoptimalkan pertumbuhan pasar modal di Indonesia. Karena pada penelitian ini variabel suku bunga SBI, harga emas, dan IHSG dapat mempengaruhi pertumbuhan NAB reksadana syariah secara signifikan. Sehingga diharapkan pemerintah dapat mengantisipasi ketika terjadi perlambatan ekonomi untuk menjaga kestabilan moneter agar mampu mengoptimalkan perkembangan reksadana syariah di Indonesia.

b. Bagi Investor baik muslim maupun non muslim agar meningkatkan investasinya ke instrumen reksadana syariah karena instrumen invetasi syariah tidak kalah dengan instrumen investasi non syariah yang juga mengalami pertumbuhan dari setiap tahunnya. Akan tetapi harus tetap memperhatikan investasi yang dipilihnya terutama terhadap faktor eksternal, karena dalam penelitian ini faktor eksternal yaitu variabel makro ekonomi juga mempunyai pengaruh yang signifikan terhadap reksadana syariah.

c. Bagi penelitian selanjutnya untuk menambah periode penelitian agar lebih lama terutama objek dalam penelitian ini tentang saham.dan pasar modal, karena dalam menganalisis saham yang merupakan investasi jangka panjang yaitu 5-10 tahun. Periode dalam penelitian kurang menggambarkan kondisi saham itu sebenarnya sehingga membutuhkan periode penelitian yang lebih lama dan mengubah objek penelitian agar lebih spesifik karena dalam penelitin ini objek (variabel independen) menggunakan data NAB seluruh produk reksadana syariah jadi tidak dapat 
Rusdiansyah, et al/Jurnal Ekonomi Syariah Teori dan Terapan Vol. 5 No. 10 Oktober 2018: 856-872;

ANALISIS PENGARUH FAKTOR - FAKTOR MAKROEKONOMI TERHADAP NILAI AKTIVA BERSIH (NAB) REKSADANA SYARIAH PERIODE JANUARI 2015 - JUNI 2017

menggambarkan bagaimana kondisi setiap produk reksadana tersebut agar investor dapat mendapatkan informasi ketika melakukan pembelian lebih dari satu produk reksadana syariah (diversifikasi).

\section{Daftar Pustaka}

Al-Qur'an dan terjemahannya. 2000. Kementrian Agama Republik Indonesia.

Burhanuddin. 2008. Pasar Modal Syariah. Jakarta: UII Press.

Bank Indonesia. 2016. Rekapitulasi Peringkat Return Investasi 2016. (http://www.bi.go.id/id/Default.aspx, diakses tanggal 23 Januari 2018)

Corrado, C. J., dan B. D. Jordan. 2000. Fundamentals of Investment Analysis, 4th Ed. Singapore: Mc Graw-Hill.

Darmawi, Herman. 2005. Manajemen Risiko. Bumi Aksara, Jakarta.

Desriani, Icha Puspita, dan Sri Rahayu. 2013. Analisis Pengaruh Pendapatan, Harga Emas Dan Tingkat Inflasi Terhadap Penyaluran Kredit. Jurnal Akuntansi dan Keuangan FE Universitas Budi Luhur Vol. 2 No. 2.

Dipraja, Sholeh. 2011. Siapa Bilang Investasi Emas Butuh Modal Gede. Jakarta: Tangga Pustaka.

Djumena, Erlangga, 2015. BPS: Inflasi 2014 Capai 8,36 Persen, (http://ekonomi.kompas.com/read/20 15/01/02/102923526/BPS.Inflasi.2014.C apai.8.36.Persen, diakses 10 September 2017).

Elvira, Yuni, dan Fiteriyanto.1997. NAB Reksadana Berlomba dengan Tingkat Suku Bunga. Jurnal Pasar Modal, No.06/VIII/Juni.

Jogiyanto, H.M. 2010. Teori Portofolio dan Analisis Investasi. Edisi Ketujuh. BPFE. Yogyakarta.

Kasmir. 2005. Bank dan Lembaga Keuangan Lainnya. Jakarta: PT Raja Grafindo Persada

Manurung, Adler Haymans. 2007. Reksadana Investasiku. Jakarta: PT. Kompas Media Nusantara.

Maulana, Akbar. 2013. Pengaruh SBI, Jumlah Uang Beredar, Inflasi terhadap kinerja Reksa Dana Saham di Indonesia Periode 2004-2012. Jurnal IImu Manajemen, Volume 1 Nomor 3 Mei 2013. Surabaya: Universitas Negeri Surabaya.

May, Ellen. 2013. Smart Trader Rich Investor: The Baby Steps. Jakarta: Kompas Gramedia

Mirazdianti, Febrina. 2014. Faktor -Faktor yang Memengaruhi Pertumbuhan Reksa Dana Syariah dan Perkembangannya di Indonesia. Bogor: Institut Pertanian Bogor. 
Rusdiansyah, et al/Jurnal Ekonomi Syariah Teori dan Terapan Vol. 5 No. 10 Oktober 2018: 856-872;

ANALISIS PENGARUH FAKTOR - FAKTOR MAKROEKONOMI TERHADAP NILAI AKTIVA BERSIH (NAB) REKSADANA SYARIAH PERIODE JANUARI 2015 - JUNI 2017

Otoritas Jasa Keuangan.2016. Pertumbuhan

Reksadana tahun 2010 - 2016.

(http://www.ojk.go.id/, diakses 12 September 2017)

Pramulia, Ronny. 2009. Pengaruh Suku Bunga, Nilai Tukar Rupiah, Inflasi, dan IHSG terhadap Deposito Perbankan Syariah. Jakarta.

Raraga, Filus, M. Chabachib, dan Harjun Muharam. 2012. Analisis Pengaruh Harga Minyak dan Harga Emas Terhadap Hubungan Timbal-balik Kurs dan Indeks Harga Saham Gabungan (IHSG) di Bursa Efek Indonesia (BEI) 2000-2013. Semarang : Fakultas Ekonomika dan Bisnis Universitas Diponegoro.

Ryandono, Muhammad Nafik. 2009, Bursa Efek dan Investasi Syariah, Jakarta: PT Serambi Ilmu Semesta.

Shihab, Quraish. 2002, Tafsir Al - Misbah Pesan, Kesan dan Keserasian Al Qur'an,Jakarta : Lentera Hati.

Sholihat, Moch. Dzulkirom AR, dan Topowijono. 2009. Pengaruh Inflasi, Tingkat Suku Bunga Sertifikat Bank Indonesia dan Indeks Harga Saham Gabungan terhadap Tingkat Pengembalian Reksadana Saham. Vol. 21 No. 1 April 2015. Jurnal Administrasi Bisnis (JAB). Malang.
Sjahputra, M. Romaz. 2005. Pengaruh Perubahan Tingkat Inflasi Nilai Tukar Uang, Tingkat Suku Bunga Bebas Risiko dan Indeks Syariah Terhadap Kinerja Reksadana Syariah. Tesis. Pascasarjana Fakultas Ekonomi, Universitas Indonesia.

Sudarsono, Heri. 2004. Bank dan Lembaga Kevangan Syariah Deskripsi dan Ilustrasi. Yogyakarta: Ekonisia.

Sunariyah., 1997. Pengantar Pengetahuan Pasar Modal. Edisi Pertama. Yogyakarta: UPP-AMP YKPN.

2004. Pengantar Pengetahuan Pasar Modal. Edisi Keempat. Yogyakarta: UPP AMP YKPN.

Wibowo, Andi. 2011. Pengaruh Variabel Makro Ekonomi Terhadap Kinerja Reksa Dana. Jurnal Akuntansi, Manajemen Bisnis. ISSN 1829 - 9857 dan Sektor Publik (JAMBSP). Surabaya.

Witjaksono, Ardian Agung. 2010. Analisis Pengaruh Tingkat Suku Bunga SBI, Harga Minyak Dunia, Harga Emas Dunia, Kurs Rupiah, Indeks Nikkei 225, dan Indeks Dow Jones terhadap IHSG. Semarang. 